\title{
中国語における呼語の性格
}

\section{大 河内康㲅}

§1 中国語に限らず，一般に人称語といわ れるものは, 話し手, 聞き手の位置の関係や話 の場を最む鋭敏に反映する言語分野と考えら れる。これは人称語の性格（コミューニケー ンヨンのあり方に規制されやすい言語形式と いうこと）から当然導かれることではある が，中国語では人称語のこのような性格がど のような特徽をもっているか。つまり話し手 対聞き手の関係,立場の差 (ascendingである か descending であるかなど, 待遇関係) が どのような形態によって主として表現されて いるか。これを呼語, vocatives〔註 1 〕い らことから考えてみたいと思う〔註2〕。

中国語の人称代詞には，人称や敬譲形式な どによって次のような対立が考えられる。 neutral courtesy

我

你 您, 你老人家, 你老, etc.

他 $\tan$ etc.

しかしこの二人称の敬譲形式,「您」「你老 人家」「你老」をとりあけてみると，これは 必ずしも「你」に対応する敬譲形式として, 待遇関係炕よって絶対に莩守されねばならな いといった性質のものではないようである。 聞き手が話し手に較べて年長者であり上位者 であるからといって，つね你」に代って 「您」,「你老人家」が用いられているとは限 らない。趙元任によると,「你」に拉ける「您」

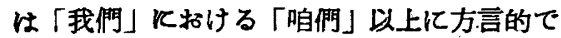
あると述べているが，「你老人家」，「你老」
そおいてもこのことは同様であり，決して日 本語に怙け「オマエ」,「アナタ」のように 相手によって敛密に使いわけのされている敬 譲形式ではない。つまりこれは待遇関係によ って対立した形式というより，むしろ「你」 に感情価值の加った補助形式として理解され るべき性質のもののようである。

そこで結論を先てするなら，中国語の人称 代詞のこのような待遇関係の表現のとぼし さ，それにはなにか補いをつけるものが予測 されるわけであるが，呼語がその役割を果し ているように思われる。属格, あるいは属格 に類したものでは, 「貫姓」,「貴处」の「責」, 「令郎」, 「令弟」の「令」,「家父」,「家兄」 の「家」などの区別がある。しかしかんじん の主格では「你」に多く依存し，その「你」 は呂叔湘のことばを借りれば「遠虑のない, 礼儀のない表現」でしかない。このことは， たとえ「貴」や「令」が属格で、你的」と対 立しろるほど広汎に用いられるすのでないと しても，主格と属格の軽重を考えるならアン バランスなととであり，「你」の場合にあな んらかの形で待遇関係の表現が行われている としなければならない。つまり ascendingの 関係に用いられた「你」にはなにか他に待遇 関係を補うような条件が加っていると理解さ れるのである。が，その条件のようなるのを 求めてみると, 呼語にあるように思われる。

[註 3 ○。 
\$2 徐社長, 奶奶找你。

沈同志, 你別怪她, 她㗪上怨, 心里可 昐你們治好虫子。

呼語というのはこの例文の一一の部分であ る。「呼語」は普通 vocatives, vocation と いわれているが，人に話しかけるときその話 とは別に句の始めや終りに独立成分として加 えられる直接の呼びかけのことば (terms of direct address) である。黎錦熙はこれを句 のなかに打ける位置ということ (呼位) から 規定し, 高名凱は sentence wordの一種（呼 句）として捉えている。またく漢語〉課本で は句諭のなかで「称呼語」と呼んでいる。い ずれる乎語がなんであるかの十分な説明がな いが，中国語ては形態素にとばしいため铱密 に呼語がなんであるか規定することは難し
い。しかし諸説をあわせるなら一応次のよう に理解されるものである。

人称語のなかで, 中降調のトーン・グルー プに入り (遡元任)，二音節のときは第二 音節沃アクント核のある（陸宗達, 俞 敏)，意味的に独立した（漢語），外位にあ る(黎錦熙) 呼びかけのととば。そして文 字に記錄されると，必ずその後あるいはそ の前に「,」,「!」が置かれ, 句そのものか ら区別される言語形式。

である〔註4】。これは指定語 (designatives) と対立して人称語という範睰を形作っている ものと考えられる[註5]。

このような呼語が，それではどのようなこ とばで構成されているかを考えるなら一応次 の表のように理解することができる。

\begin{tabular}{|c|c|c|c|c|c|c|c|}
\hline 関 & $\begin{array}{l}\text { 親 } \\
\text { 密 } \\
\text { さ }\end{array}$ & 呼 & 加 成 分 & $\begin{array}{c}\mathrm{A} \\
+0 \text { の形式 }\end{array}$ & $\begin{array}{c}\text { B } \\
+ \text { 姓の形式 }\end{array}$ & $\begin{array}{c}C \\
\text { +名の形式 }\end{array}$ & $\begin{array}{c}\mathrm{D} \\
+ \text { 老の形式 }\end{array}$ \\
\hline 非 & 1 & I & 職 & $\begin{array}{l}\text { 院長, 主任 } \\
\text { 社長, 卖畫 } \\
\text { 同志, 先生 }\end{array}$ & $\begin{array}{l}\text { 梅主任 } \\
\text { 趙畫記 } \\
\text { 吳 向志 }\end{array}$ & 綺文同志 & $\begin{array}{l}\text { 老主任 } \\
\text { 老社長 } \\
\text { 老先生 }\end{array}$ \\
\hline 親 & 2 & $\mathbb{I}$ & 姓 & $\begin{array}{l}\text { 自立形式 } \\
\text { ではない }\end{array}$ & - & $\underset{l}{\mathbb{N}} \underset{\text { 同 }}{ } \mathrm{B}$ & $\begin{array}{ll}\text { 老 } & \text { 丁 } \\
\text { 老 } & \text { 張 }\end{array}$ \\
\hline 属 & 3 & & $\begin{array}{l}\text { 転用された } \\
\text { 親属呼称 }\end{array}$ & $\begin{array}{l}\text { 伯 } \\
\text { 畋 }\end{array}$ & $\begin{array}{l}\text { 銭伯伯 } \\
\text { 魏叔 }\end{array}$ & $\begin{array}{l}\text { 德 明 歌 } \\
\text { 梅 姐 }\end{array}$ & 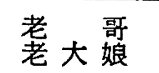 \\
\hline 親 & 4 & & 名 & $\begin{array}{l}\text { 贾 喜 } \\
\text { 英 }\end{array}$ & $\begin{array}{l}\text { 張 玉 英 } \\
\text { 陳, 国 }\end{array}$ & 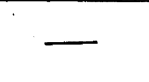 & \\
\hline 属 & & & 親属呼称 & $\begin{array}{ll}\text { 妹 } & \text { 妹 } \\
\text { 表 } & \text { 哥 }\end{array}$ & $\begin{array}{l}\text { 陳 姨 太 } \\
\text { 沈 姨媽 }\end{array}$ & $\begin{array}{l}\text { 琴表 姐 } \\
\text { 賞明塥 }\end{array}$ & \\
\hline
\end{tabular}

この額内に見られる「院長」「梅主任」などはそれぞれそのような形式をもつものの

一例にすぎな。「先生」「同志」は職名のなかに加えた。同様にに「小姐」の ようなものも含む。

呼語はどのような人称語でむその时时に よって自申に呼語になるという性翼のすので はない。「工人」,「朋友」、「農民」といった人
称名詞（これは人称語のなかで大多数を占め る）はいつむ指定語としてのみ用いられ，呼 語に用いられることはない。呼語になりらる 
むのは人称語のなかでも限られており，した がってまたそれによって構成される呼語のフ オームもはぼ一定している。職名 (ititle), 姓, 名, 親属呼称, および転用された親属呼 称（親属でい人反用いられる親属呼称）か 乎語を形作る主要なものであり，これに附加 成分が結びついて呼語の種々のフォームがで きあがっている。

あち論, この表にすべて尽されるほど呼語 は単純なものではない。呼語はパロール的な むのであり，その場その場に応じた使われ方 がある。例えば, その会話の行われるところ が閉鎖的な山村であるか，開けた都会地であ ろか, またその話の内容が private であるか publicであるか, 話し手のその时の感情は等 等の事情によってかなり異ってくる。ことに 附加成分は話し手の感情価値によって多くの 形式がある[註6]。しかし㭔語として安定し た一般的なむのを求めるなら，一応この表に みられる形式が呼語のおよそのフォームであ って「からVまで，A〜Dをかけあわせた14 のあのが考党られる。つまり「好孩子」の上 うな臨时的呼語を除くなら，ほとんどのもの は職名からきたもの, 姓名からきたもの, 親 属呼称からきたすののいずれかになる。ただ との場合，聞き手と話し手の間に親属のよう な特殊な関係があるかどうかは最初考えて おかねばならないことで，「親属呼称」は親 属の間でしか用いられないのはいうまであな
い。親属呼称については趙元任氏の詳細な研 究があるので,ここでは問題を非親属（I～ IV, A D , 11の形式）に限ってとりあげる 〔註7〕。

§3 非親属について呼語はそのスタイルか ら11の類形に分けることができる。しかしこ の11の形式の間にどのようなちがいがあるか ということであるが，これには単純に字面か らたどられる意味や構成にちがいがあるとい うばかりでなく, 話し手, 聞き手の位置の関 係, 待遇関係によってはっきりした使いわけ が行われている。「梅主任」という場合と，

「主任」という場合と，「老主任」という場 合と，さらには「老梅」という場合とにはそ れぞれちがった話し手, 聞き手の関係がある。 呼びかけられるのが同じ梅主任であるなら， これらの形式の間ては呼びかける人の交代が 予測されるのである。つまりこれらの形式は 話し手の任意の選択にまかされて用いられて いる，というものではない。そのことばが年 長の, 重要な職務にたずさわっている人に向 けられたむのであるか，あるいは年少の同哑 以下のあのに向けられたものであるか，また その間の開きはどの程度であるかなどによっ て, 呼語のこれらのフォームにはかなり整っ た使いわけがみられるのである。

〈殷本>1958年 1 月号の「青春之歌」とい う脚本を例飞とってみると，次の表のように なる〔註 8 〕。

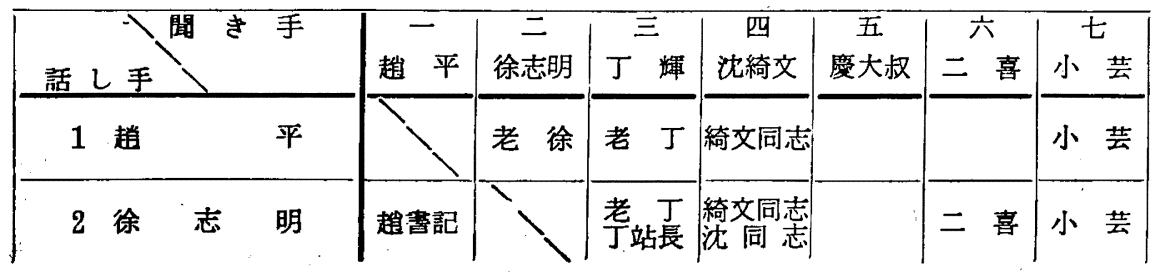




\begin{tabular}{|c|c|c|c|c|c|c|c|c|c|c|}
\hline 3 & 丁 & & 輝 & 趙書記 & 徐社長 & & 綺 文 & & & 小 芸 \\
\hline 4 & 沈 & 綺 & 文 & 趙書記 & 徐社長 & 丁 輝 & & & 二 喜 & 小 芸 \\
\hline 5 & 慶 & 大 & 叔 & 趙書記 & $\begin{array}{l}\text { 徐社長 } \\
\text { 社長 }\end{array}$ & $\begin{array}{l}\text { 丁站長 } \\
\text { 丁同 }\end{array}$ & 沈同志 & & 二 喜 & \\
\hline 6 & $=$ & & 喜 & 趙書記 & 社 長 & 丁站長 & 沈同志 & 大 叔 & & - \\
\hline 7 & 小 & & 芸 & 趙書記 & (社長) & 丁站長 & 沈同志 & - & - & \\
\hline
\end{tabular}

1. 趙平；この芝居の舞台になる村へ以 前から来ている区委員会書記, 29才。2. 徐志 明；合作社の社長, 40才 3. 丁輝；下郷 運動で，この村の合作社に新しく設けられた 扱術推進所に下放してきた大学卒業生, 23才 少さいなからら技術推進所の所長 4 , 沈綺 文；丁輝のクラスメートで，とむにこの合 作社任下放してきた女性, 22才, 所員 5 . 慶大叔； 合作社の社員, つまりこの村の農 民，40才 6. 合作社の社員，20才 7. 13才 女児一これらの人たちがどのような呼語を 使って拉互を呼びあっているかというととで ある。

1から7まで，一応重要な職務にある人から また年長者から順次並べられているが，同じ 人が話し手が変ることによって異った呼語で 呼ばれていることが加る。斜線より上は descending, 下はascending の呼語と考兄ら れる[註9]。1の趙平は, 自你か呼びかける ときは「老徐」「「老丁」,「綺文同志」; 「小芸」 といった呼語を用いているが，人に呼びかけ


趙」「趙同志」「趙平」と乎びかけられるこ とはない。をた 3 の丁輝，4の沈綺文は趙平， 徐志明には「老丁」,「綺文同志」之呼びかけ
られているが，これ以外の人たちには「站 長」「沈同志」と呼びかけられるのであって 「老丁」や「綺文同志」た用いられるととは 決してない。つまりての場合, 2 の徐志明が

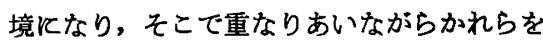
呼ぶための用語が移行しているとみられれる のである。二喜,小芸は他の誰よりも年少であ り，また職務の上からむ下位であるため,「二 喜」「小芸」と名で乎ばれ，それ以外の呼語 が用いられるととはない（この脚本の最初の 登場人物説明の部分で，すでかれらの姓は 不問にされている。しふしてのととはこの芝 居でかれらが「て他大勢」に入る人たちだ からではない） 5 の䍗大叔は，かれが職務 の上では下であるが, 年令の点では上である といったとまどいから呼語の使用がさけられ ている。概してての表から，斜線の上と下， 表の左よりと右よりによって呼語のフォーム がちがうととが読みとられる。これらの人た ちはその職務によって括よそ三つのクルーフ 1 と 2,3 と 4,5 と 6 と 7 亿分けるととがで きる(年令は二義的である)。しかしての三 つのグループの間で呼語ははっきりと使いか けされているのであり, 待遇関係, 位置の関 係は相対的とではあるが，それぞれの間で使 
われる呼語を規定しているのである。

田漢の「十三陵水庫暢想曲」(<磷本 $>1958$ 年 8 月) 飞次のような部分がある。

副政委; 閻秀蘭，她原来是个市放干部，加 入农民姐妹的隊伍参加学动。起先人家叫她 「老闃」。后来叫她「閻大姐」，后来去了 「閻」字叫她「大姐」。这説明她农民化, 工人階級化一天天加深，因此她成了她这个 集体的有威信的領袖。……...

とれからす，呼語が待遇関係，位置の関保に 裹ずけされた感情（それは半固定的である） てよって規定されていることが筧われる。閻 秀蘭がその村飞やって来たとき，人々は「老 間」と呼びそれ以外の方法でかの女を呼げな かった。そして次の段階では「閻大姐」と呼 び，「老間」とはいっても「大姐」とは決し て呼ばなかった。このことは呼語が随便」 なあのでないというととであろう。まだこ のように呼び方の変ったということが，かの 女か「農民化」し，「工人階級」化した証佐 とみられるからには, その根底に, 呼び名は 待思関係と密接な関係にあり, むしろ待遇関 係の表明であるとする考学があることはいう までもない。ある女性が「農民化」したとい うことの気のきいた紹介がこのような表現を とるというととは，それだけで呼語と待湡関 係のつながりについて十分に語っている。

待遇関係抙語を規定する。 ascending, descending の関係にはそれぞれそれてふさ わしい呼語がある。てのととは，また逆㑆見 るなら，上位者に向けられる呼語によって上 位者に対する敬意を表明するということであ ろう。事実, 呼語か用いられている例を調べ るなら descending の関係より ascending の関係炕圧倒的䎲多い。つまり descending そ招いて不必要であっても ascending では
「礼貌」を表明するため是非必要な場合が少 くないというととである。したがって，呼語


よって一応の序列を求めるととができるが，

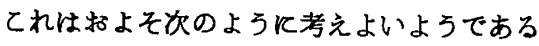

〔註10]。

I B 梅主任, 李書記など

I A ( I C) 院長, 社長など

I D 老主任, 老社長など

I D 老張, 老李など

III B 銭伯伯, 尅大叔など

II C 德明哥, 海旺叔など

III A 伯母, 大嫂など

III 老弟，老大娘など

IV A 二喜, 小芸など

IV B 王良など。これは姓, 名がともに 一音節のときに限る〔註11〕。

むち論ここにあげた順序は和よその序列で あり, いっも正確にこうなるといったもので はない。呼語の選択がすで, 話し手の心理 や性格に上って動くものである以上普遍的に 正確な序列など求めるへくもない。したがっ ててれは一つの傾向であるが，その意味では く劇本〉などの多くの資料によったあのであ る。たと充，蘇民という区委員は，中年以 上の村民からは「区委」と呼げれるが，若い 人からは「蘇区委」と姓を冠して呼ばれる傾 向がある。合作社の社長は，かれと世代を同 じくする農民からは「老社長」と呼ばれても 若い人久からはむしる「社長」と呼ばれるこ とが多いのである。ただ「同志」のような新 しいととい゙は, 中国語のなかで十分定着して いないため,「同志哥」「老趙同志」のよう なくずれたいい方があるとはいえ，どちらか といえば public な場所や全く未知の人を呼 ぶときに多く用いられて抲り，呼語のなかて 
どのように位置ずけるが難しい。概して他 の呼語の用法のアナロジーから水平化の力が はたらいていることはいうまですない[註6]。 呼語のこのような待遇関係の序列は, 日本 語の場会とずいぶん開きがあると思われるが これは雬訳の上で難しい問題であろう。「林

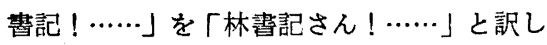
ては，ことばを监き換えただけのことであっ て，「林書記！」のもつ場面をわれわれは

「林書記さん!」から想像することができな い。つまり「中村課長さん」は日本語で最も courtesy な呼語にならないということである 呼語は，そのような呼語が用いられるための 場面の必然を背負って用いられているのであ る 註12\}。

§7 王力はく中国語法理論〉のなかで次の ようにのベている。

中国には古くから人称代詞で上位者, ある いは同輩を呼ぶのを礼儀を知らない，はし たない行為としたっしたがって古人は，人 を呼ぶのにある種の敬讓式を使ったが，そ れは代詞を用いずに名詞（官職など）を用 いることであった。〔註13〕

しかしこれは言語の実際からみるとおかし なことで，人称代詞とそれに代るべき名詞と が，それほど容易にさしかえできるものとは 思われない。エスペルセンは＜Philosophy of Grammar>で.,

I see you.

Otto Jespersen sees Mary Brown. の二つの例をあげて, この「I」が「Otto」 Jespersen」の代用であり，「you」が「Mary Brown」の代用であるとするのは萧朴な心に いかにす不自然感じられるとのへ，「代」 の字を問題にしている。事実, 代詞には代詞
としての用いられるところがあり，名詞には 名詞として用いられるところがあるわけであ ろう。そして日常の会話の場では代詞が絶対 の座を占めるのであり，たと古人です「人 称代詞を用いず，名詞を用いた」というのは spoken 飞関する限りころ簡単にいいきって しまえるものではないと思われる。もっとす 王力のいうことは written に括いては全く正 しいのであるから,てその意味に括いて王力に は spoken と witten の無意識の混同があっ たと考をられる。

したがって，それでは王力のいうととを話 しことば spoken ではどのように理解すれね よいか,つまり中国語の人称代詞には敬謪式 があるという王力の主張を, エスペルセンの 説とどのようと結びあわせて考えれはよいか ということであるが；これは主格に関する限 り次のように考えてよいのではないかと思 う。つまり，代名詞はエスペル七ンのいうよ うに代名詞が本来こなければならない位置に くる。そして王うのいう名詞はその代り外位 成分, 呼語となって外飞出るということであ る。

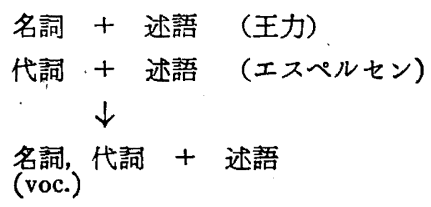

つまり外位成分を別にとる，いわば欲の深 い方法で国中語の礼貌式は落ちついていると 考えられるのである[註14]。

呼語の本来の役割は, 話しかける相手が誰 であるかを明かけする。またその相手の注意 を薏くことにあると思われる。しかし中国語 でこのことは次第に二義的なすのになりつつ ある。そしてそれがしきりに使われろ最大の 
理由は，「小的特来与閣下棓議」といった表 現のなくなった中国語で人称代詞に代って話 し手聞き手の位置の差を補埧することにあ ろ。呼語は単に addressing terms というの ではなく，特殊な外位成分としての性格をに なっているということから考えてよいのでは なかろうか [註15]。

(この稿は今年の中国語学会での発表「中 国語に猢る呼びかけ語について」をま とめたすのである)

註1. 呼語については＜馬氏文通＞以来印欧 語の文法体系ととむに入った「呼格」の概念 をめぐって種々批判的な立場がある。中国語 では乎語を morphologyの立場からとらえら れない以上, 所詮てれらの見解も当然なもの と思われる。したがってここでとりあげる呼 語は中国語に呼格, 呼位があると主張しての ものではなく，人称語の範略のなかで考学た あの,「つまり人称語のなかで呼語が果す機 能から逆にとりあげたものである。

註2. 国語学者の西尾実氏によると，言語に よって行われるコミューニケンヨンのあり方 を, 対話的関係 (二人), 会話的関係(数人), 公話的関係 (一対多) と区分されている。日 常の口頭言語ではコミユーニケーンョンのあ り方がその言語形式を決定する重要なエレタ ントであり，殊に人称語ではそのような「話 の場」を考㦄して抢く必要がある。

註3.「令」,「家」「貴」はどちらかといえ
ば文章語である。しかしまた，これらが口で 話されていることもまちがいない。ことばの 「闘いはいつの時代でも。過ぎ去った幾世紀 ものテキストを手本としてまもる保守主義と 教育について「持てるもの』である社会層の 階級的抵抗をものともせず隹，文語と口語を 近ずけようとする近代精神との間に行われ る」（マルセル・コエン）が, 主格と属格の 間にはンフター (shifter) に時間的ズレがあ るものと思われる。

註4. 黎錦熙 ; 新著国語文法 30.71 頁。比 較文法 16 頁。高名凯; 漢語語法論 540 頁。漢 語課本第 4 冊104頁。簡略句・無主句・独詞 句 (漢語知識誨話) 49.50 頁。趙元任., Mandarin Prinrer. Chinese Terms of Address(Language. Vol 32. Nol. JanuaryMarch 1956. Journal of the Lingustic Society of America). 陸宗達, 俞敏; 現代漠語 語法上冊 29. 30頁.

註5. 人称語を名詞のなかで非人称語とわけ るととはトラゴノフが指摘している通り必要 なことと思われる。人称語をどのような体系 で理解するかはいるいる方法があると思われ ろが，ここでは呼語，指定語の対立を考えて 抢く。指定語とは句の中である人を指示, 指 定することば，さきの例文では「奶奶」，

「你」「她你們」などである。中国では「当 面称」「背面称」といわれているものがこれ 飞近い(中国語文，1958年 9 月 432 頁)。タ イヤグラムにすると次のようになる。

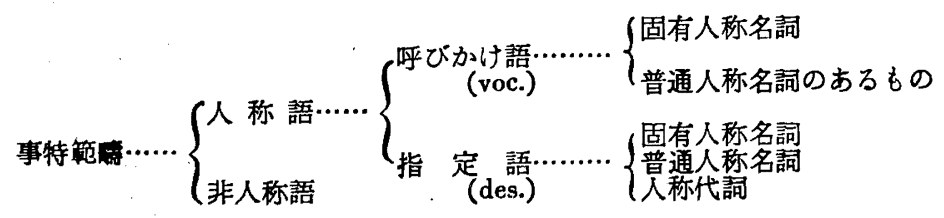


铨6.<劇本>1957年 7 月「列車在行進」そ 次のよううな例がある。

列車のなかで乗務員の帳一民とある抢客が お茶のことで激しくいい争っている。そこへ 同僚があらわれる。

老恐；（連忙把張一民扯開）少説一句吧，張 一民同志。(向旅客) 同志。你喝什么茶 ?

一位旅客., 泡一杯緑茶吧。 老恐；（転身拉張一民至乗务員室前）小帳， 怎么 gao 的? (張不語) 有 sha 不痛快? 「張一民同志」と「小張」が扮客の有無によ って使いわけられている。「フル・ネーム+ 同志」は最もパプリックであり，プライベー トになるにつれ「小」,「老」などの特別な附 加成分がつく。

註7. 趙元任., Chinese Terms of Address

(註 4 参照)

註3.この上ろな資料の選択には，登場人物 の位置の関係任できるだけ巾のあること，ま たそのような人たちが親属や親しい友人など の特殊な関係で結ばれていないこと，その社 会が軍隊や学校など特別なものでないことが 条件となる。その意味で $5 \bullet 4$ の頃の戯曲には 「密斯」などが続出して，資料としてとりあ ゲるには細心の注意が必要である。

墪9.この表にみられる使いわけは ascending descending ということと同時に， 親密さと いうことにも関係してくる。しかしこれを親 密さということだけに罡元してしまうことは できない。つまり 1 の趙平と 2 の徐志明とは 趙平がこの村に来てからのつき合いであり， 親密さは趙平からいっても徐志明からいって あ同じである。にもかかわらずお互が呼びあ う呼語は異った形式をもつからである。との ととはすへての場合にあてはまる。だだ異っ
た場では，それぞれの場の中で羅った序列が あるかも知れないというととである。 註10. この問題はつきつめると言語心理学の 領域のものとなる。ここではできるだけ感情 や話し手の心理を髉れて問題を扱うこととす 万。

襩数の人に対する呼語が少いということも 呼語か「礼貌」の表明であることと関連する のではなからろか。待遇関係々゙個人対個人を 基調にする。複数の人に対する呼語には次の ようなものがある。

同志們，社員們，郷漞們，請各位旅客注澺

(これは「みなさん!」に当る des.)

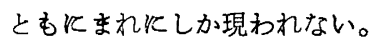

註11.これについて趙元任は次のようKのべ ている。「名はすし単音節であるなら，単音 節の姓の場合と同様飞 bound form であり， 必ず前に姓をつけるか後に親属呼称を加えて 話される。例えげ王良，良舁，良鼠威のよう に………として誰にす「良』と呼ばれること はない。なぜなら【良』が free でないから である」つまり bound と bound とが結び ついて free になるといら条件が必要であ る。

註12. ある橎訳の一部をひく。

我們只得站在外面向裹「大姐! 大嫂!」的

喊——「ごめん下さい! こんにちわ!」

と中へ教回よびかけるより手はなかった。 またある部分では，

女同志，你去借吧………。站光！招ま元さ

んいって借りてくれょ……....

ともに苦心のあとがしのばれる。

註13. 中国自古就以㖶用人称代詞称呼尊輩或 平经为一种没有礼貌的行为。因比古人刘於称 呼有一种礼貌式，就是不用人称代詞，而用名 詞（官職などを指す）。 
睡14. 呂叔湘はく文法要略〉のなかで次のよ うな例をひいている。

我們知道你是好心, 不过你和太太説涪, 不 必这样発急, 「你」呀「我」的, 没了規矩 （男士., 我的奶娘）

もっとも解放後に招いては，「近代不如古 代，現代又不如近代」(王力）て「没了規矩」 では決してない。しかし「你」では扰さまら ない感情表現があると思われる。これは「您」 以外には呼語に依存する。＜紅楼夢＞では 「您」がない。「你老人家」の使用む限られ ているようである。ascending の関係に拄い て最も頻繁にあらわれるのは teknonymy つ まり他のあのの立場からする呼び方を利用し てあろ人を呼ぶととである。

二人称の襩数が二人称の敬讓式になるのは 多くの言語に共通してみられるが，エスペル センは<Growth and Structure of The English Langerage> のなかて次のようKの べている。「一人の人に袮数の代名詞を以て 呼びかける習慣はその起源に括いては確かに 階級的差別を助長する貴族的傾向の結果であ った。この習慣はローマの皇帝たちが普通の 一個人ょり以上の価値古るあとして呼びか けてもらいたいという希望加始まった。… ……」むちろんこれは中国語の「您」とは別 の問題である。

註15.なお，呼語のような性格は，大なり小 なり言語一般に存在することのようである。
しかしこれについては, シャルル・バイイが 次のようにのべている。きわめて示陖的なこ とばであるので, 最後に引用しておく。

言語の輠造を一層簡単に, 一層規則的に, 一層線的にし，体系の分子の交換可能性に よってその働きを容易ならしめるとてろの 莫大量の事夷をわれわれは眼の前にしてい るのである。…………近代語の向うところ は，一切合財発明飞なる人工語が幾分なり と到達するところにはかならない。 それらの変化の目的は, 伝達を一層速やか 飞一層手軽炕することである。しかしなが ら今からこう問うてみることができようと 思う。そうした方向に進化する言語か，い かにして依然表現に適するか，換言すれば 情緒を，感情を，欲望を，思惟のあらゆる 直観的個人的形態を，そのすへてての強さ， そのすへての細かさに扔いて，写しだすこ とができるか，一言にしていえば，ただに 集団の欲求のみならず，な扔個人の欲求を も满足せしめうるか。

事実, 伝達の傾向と表現の傾向とは, 和 解すべからざるものの如くにみえるのであ る。(小林英夫訳 ; <言語活動と生活 $>234$, 5頁。な打集団の欲求」とは, バイイが, 言語の単純化を反省的, 言語集団の意志的 なものとみているととを指す) 